
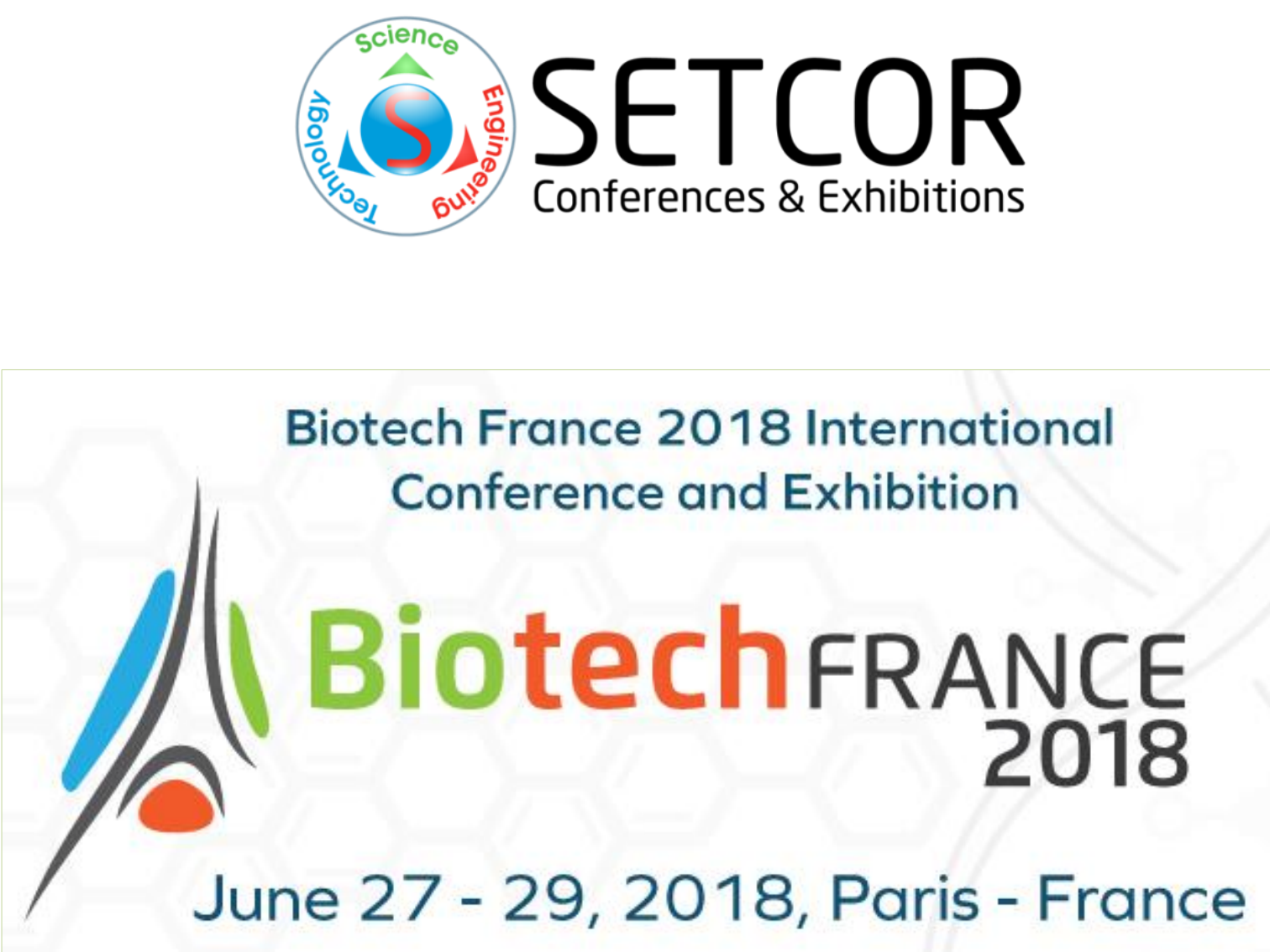

The International Biotechnology Conference \& Exhibition Biotech France 2018

June 27 to 29, 2018, Paris - France Conference Proceedings

DOI: https://doi.org/10.26799/cp-biotechfrance2018 


\title{
Production and use of microbial biomass helping sustainability in fish production chain
}

\author{
Elisa H. G. Ponsano ${ }^{1}$, Thiago L. M. Grassi ${ }^{1}$, Edson F. E. Santo ${ }^{2}$, Leandro K. F. Lima ${ }^{3}$, \\ Raquel C. Pereira ${ }^{4}$ \\ ${ }^{1}$ UNESP Univ Estadual Paulista, Faculty of Veterinary Medicine, Araçatuba SP, Brazil \\ elisahgp@fmva.unesp.br; thiagograssi@fmva.unesp.br \\ ${ }^{2}$ Federal Institute of Education, Science and Technology, Manaus AM, Brazil \\ edson.santo@ifam.edu.br \\ ${ }^{3}$ EMBRAPA Brazilian Agricultural Research Corporation, Palmas TO, Brazil \\ leandro.kanamaru@embrapa.br \\ ${ }^{4}$ Centro Universitário de Adamantina, Adamantina SP, Brasil \\ raquelpereira@fai.com.br
}

\begin{abstract}
This study represents an example of the classical concept of biotechnology as "the use of living organisms to make useful products and provide services". Its purpose was to investigate the ability of phototrophic bacterium Rubrivivax gelatinosus to cause the depollution of an industrial byproduct and work as an ingredient for animal feed as a way of making the productive process more sustainable. First, the bacterium was grown in fish industry effluent (inoculum at $1 \% \mathrm{v} / \mathrm{v}, 30 \pm 5{ }^{\circ} \mathrm{C}, 2000 \pm 500 \mathrm{lux}, 7$ days) and recovered as a biomass (microfiltration + centrifugation + lyophilization), resulting in a decrease of ca. $80 \%$ in the Chemical Oxygen Demand of the pollutant effluent and so placing it within the required limits for wastewaters discard in Brazil. Next, the biomass was characterized as a non toxic product (hippocratic screening) provided of nutritional and technological properties due to its composition - $46 \%$ protein, $17 \%$ lipid, $5 \%$ minerals and $0.3 \%$ red oxycarotenoids. Further, the biomass was used as an ingredient to feed cultured tilapias $(0,175,350,700$ or $1400 \mathrm{mg} / \mathrm{kg}, 80$ days $)$ providing increases on the redness well as on the protein and the carotenoid contents of the fish fillets, besides a delay on the meat rancidity up to 80 days of storage under freezing. So, it was demonstrated the biotechnological application of $R$ gelatinosus biomass, contributing to the sustainability in fish raising and processing and so providing benefits to environment, industry and consumers.
\end{abstract}

Keywords: Chemical Oxygen Demand, color, effluent, rancidity, $R$. gelatinosus, tilapia.

\section{Introduction}

Biotechnology may be classically defined as "the integrated use of biochemistry, microbiology, and engineering sciences in order to achieve technological (industrial) application of the capabilities of micro-organisms, cultured tissue cells, and parts thereof' [1]. In this broad sense, Biotechnology covers many contemporary sectors, from pharmaceutical, medical and agricultural until environmental and food production. Despite the field of application, our understanding is that Biotechnology must be consolidated as a science with the ultimate goal to benefit humanity.

Rubrivivax gelatinosus is a Purple Non Sulfur Bacterium able to exert diverse metabolic routes, using different substrates and growth conditions, what enables it to play a role in the remediation of the environment. As a phototrophic bacterium, $R$. gelatinosus produces bacteriochorophyll $a$ and oxycarotenoids, the latter working as accessory pigments to absorb the light energy during the photosynthetic process [2]. These features of $R$. gelatinosus sharpened our interest in investigating the bacterium as an agent in biotechnology, particularly for the depollution of food industry effluent (so 
causing a service to the environment) and as an ingredient for animal feeding (so providing a product to agriculture), which were the aims of this study.

\section{Materials and Methods}

Rubrivivax gelatinosus used in the experiments was isolated from poultry slaughterhouse wastewater and confirmed on the basis of morphology, biochemical pathways and phototrophic pigments and was maintained in stock medium at $-20{ }^{\circ} \mathrm{C}[3]$. The strain was gradually reactivated in synthetic medium to be used as the inoculum, according to procedures previously described [4].

The substrate used for the production of the bacterial biomass was the effluent derived from fish industrialization, which was analyzed regarding to total solids (TS), total nitrogen (TN), oils and greases (OG) and Chemical Oxygen Demand (COD) (APHA, AWWA, WPCF; 2005). The effluent was filtered $(5 \mu \mathrm{m})$, heated at $60-65^{\circ} \mathrm{C} / 30 \mathrm{~min}$, cooled to $30^{\circ} \mathrm{C}$ and disposed into $100 \mathrm{~L}$ glass reactors to receive the bacterial inoculum at $1 \%(\mathrm{v} / \mathrm{v})[5]$.

The reactors were completely filled and stoppered to provide anaerobiosis and the cultivation lasted 7 days at $30 \pm 5{ }^{\circ} \mathrm{C}$ and $2.000 \pm 500$ lux. The biomass was recovered by the microfiltration of the cultured effluent (Frings membrane unity $0.75 \mathrm{~m}^{2}$, porosity $0.2 \mu \mathrm{m}$, flow $1.5 \mathrm{~m}^{3} / \mathrm{h}$, pressure 1.5 bar), followed by the centrifugation of the retentate (Incibrás Spin VI, 3,400 x g, $5^{\circ} \mathrm{C}, 30 \mathrm{~min}$ ) and the lyophilization of the frozen pellets (Liobrás L 101, $65^{\circ} \mathrm{C}, 48 \mathrm{~h}$ ) [5]. The permeate generated from the microfiltration was analyzed for TS, TN, OG and COD using the same methodologies cited above and the $R$. gelatinosus biomass obtained was analyzed for proximate composition [6] and oxycarotenoids content [7].

For the essay on acute toxicity, Wistar rats received via gavage at single dosage either corn oil or the bacterial biomass at $300,1,000$ or 2,000 mg biomass $/ \mathrm{kg}$ body weight dissolved in corn oil (Guideline 423 OECD, 2002). During 15 days, the animals` behavior (Hyppocratic Screening) and physiological signals (weight, feed intake, water consumption, excreta production and temperature) were monitored [8].

Next, the biomass was tested as an ingredient in tilapia diets. A completely randomized design with five treatments and four repetitions was adopted. The tilapias (Oreochromis niloticus) were distributed into 24 tanks (1,000 L/ 40 fish/tank) and received ad libitum during 80 days one of the experimental diets: control group (basal diet) and T1 - T4 - basal diets plus Rubrivivax gelatinosus biomass at 175, 350, 700 or $1400 \mathrm{mg} / \mathrm{kg}$. Tilapia and diets weights were recorded and, once a week, the sediments in the tanks were siphoned and the water quality parameters were monitored. After slaughter and filleting, the fillets were analyzed for proximate composition [6,9], carotenoid content (extraction with acetone / absorbance at $475 \mathrm{~nm}$ ), color (CIELab) and rancidity [10]. The results were analyzed by ANOVA and the means were compared at $5 \%$ significance level.

\section{Results and Discussion}

The effluent in natura contained high concentrations of organic matter (COD 1,127.5 mg/L, TS $1.5 \mathrm{~g} / \mathrm{L}$, OG $1,166.3 \mathrm{mg} / \mathrm{L}$ and TN $813.3 \mathrm{mg} / \mathrm{L}$ ), which denoted its pollutant potential for the environment. However, the operations used for the treatment of the effluent in natura described herein provided the removal of $82 \%$ in COD, $40 \%$ in TS, $48 \%$ in OG and $22 \%$ in $\mathrm{TN}$, rendering it suitable for discharge in the environment, according to Brazilian laws [11, 12]. So, the biomass production process itself worked as a depolluting treatment for the tilapia fish industry wastewater, so confirming the ability of $R$. gelatinosus to provide a service to the maintenance of the environment.

R. gelatinosus biomass had $4 \%$ moisture, $5 \%$ ash, $46 \%$ protein and $17 \%$ lipids, a composition that reinforced the suggestion of using it as a nutritional ingredient for animal rations. Moreover, the biomass contained $0.3 \%$ oxycarotenoids, recognized as antioxidant substances, with the particular ability to deposit on animal tissues $[13,14]$. These features plus the absence of deaths or signs of adverse effects 
of the product on the rats tested for acute toxicity encouraged us to investigate its role as an ingredient in fish feeding.

As the use of the biomass increased the concentration of protein in the tilapia muscles (Table 1), it is feasible to believe that it features the capacity of improving the absorption and deposition of proteins in the fillets, like a probiotic power. The increase in the concentration of $R$ gelatinosus biomass also increased the concentration of carotenoids in the tilapia fillets and the redness of the color, so confirming the ability of the biomass oxycarotenoids to deposit in the flesh and provide color enhancement (Table 2). The increases in the protein content and in the redness of the fillets were explained at $98.2 \%$ and $99.45 \%$, respectively by the increase of the biomass in the fish diets (Figure 1).

Table 1. Means $( \pm \mathrm{SD})$ of the proximate composition of the fillets of tilapia fed different concentrations of Rubrivivax gelatinosus biomass

\begin{tabular}{ccccc}
\hline Treatment & Moisture $(\%)$ & Protein $(\%)$ & Lipid $(\%)$ & Ash $(\%)$ \\
\hline Control & $79.03 \pm 0.60^{\mathrm{a}}$ & $18.02 \pm 0.46^{\mathrm{b}}$ & $1.16 \pm 0.08$ & $1.30 \pm 0.09$ \\
T1 & $77.78 \pm 0.29^{\mathrm{b}}$ & $19.49 \pm 0.43^{\mathrm{a}}$ & $1.20 \pm 0.32$ & $1.23 \pm 0.10$ \\
T2 & $77.26 \pm 0.44^{\mathrm{b}}$ & $19.43 \pm 0.42^{\mathrm{a}}$ & $1.22 \pm 0.19$ & $1.34 \pm 0.08$ \\
T3 & $77.23 \pm 0.64^{\mathrm{b}}$ & $19.53 \pm 0.58^{\mathrm{a}}$ & $1.38 \pm 0.16$ & $1.38 \pm 0.05$ \\
T4 & $77.41 \pm 0.41^{\mathrm{b}}$ & $19.55 \pm 0.53^{\mathrm{a}}$ & $1.32 \pm 0.16$ & $1.32 \pm 0.15$ \\
\hline P value & 0.0005 & 0.0013 & 0.5218 & 0.3740
\end{tabular}

$\mathrm{T} 1-175 \mathrm{mg} / \mathrm{kg}$ biomass; T2 - $350 \mathrm{mg} / \mathrm{kg}$ biomass; T3 - $700 \mathrm{mg} / \mathrm{kg}$ biomass; $\mathrm{T} 4-1.400 \mathrm{mg} / \mathrm{kg}$ biomass. Means followed by different superscripts differ significantly at Tukey`s test $(\mathrm{p}<0.05)$.

Table 2. Means $( \pm S D)$ of the color attributes and the carotenoid content of the fillets of tilapia fed different concentrations of Rubrivivax gelatinosus biomass

\begin{tabular}{ccccc}
\hline Treatment & Lightness (L) & Redness $\left(\mathrm{a}^{*}\right)$ & Yellowness $\left(\mathrm{b}^{*}\right)$ & $\begin{array}{c}\text { Carotenoids } \\
\text { content }(\mathrm{mg} / \mathrm{kg})\end{array}$ \\
\hline Control & $52.83 \pm 0.95$ & $1.32 \pm 0.16^{\mathrm{c}}$ & $10.83 \pm 0.38$ & $3.34 \pm 0.41^{\mathrm{b}}$ \\
T1 & $52.59 \pm 1.82$ & $1.88 \pm 0.14^{\mathrm{b}}$ & $10.98 \pm 0.84$ & $5.30 \pm 0.21^{\mathrm{a}}$ \\
T2 & $51.78 \pm 1.69$ & $2.26 \pm 0.19^{\mathrm{a}}$ & $10.73 \pm 0.84$ & $5.29 \pm 0.22^{\mathrm{a}}$ \\
T3 & $52.58 \pm 0.52$ & $2.57 \pm 0.18^{\mathrm{a}}$ & $11.76 \pm 0.41$ & $5.69 \pm 0.90^{\mathrm{a}}$ \\
T4 & $52.26 \pm 2.43$ & $2.55 \pm 0.10^{\mathrm{a}}$ & $12.05 \pm 1.83$ & $5.79 \pm 0.54^{\mathrm{a}}$ \\
\hline P value & 0.9077 & $<0.0001$ & 0.3144 & $<0.0001$
\end{tabular}

$\mathrm{T} 1-175 \mathrm{mg} / \mathrm{kg}$ biomass; $\mathrm{T} 2-350 \mathrm{mg} / \mathrm{kg}$ biomass; T3 $-700 \mathrm{mg} / \mathrm{kg}$ biomass; $\mathrm{T} 4-1.400 \mathrm{mg} / \mathrm{kg}$ biomass. Means followed by different superscripts differ significantly at Tukey`s test $(\mathrm{p}<0.05)$.

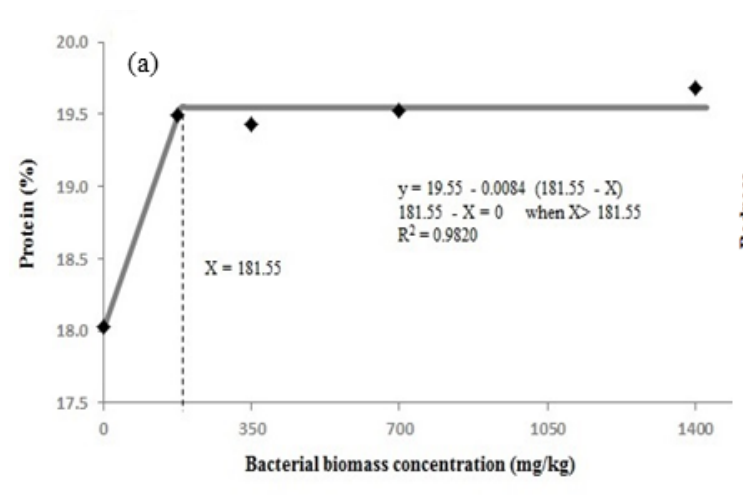

(b)

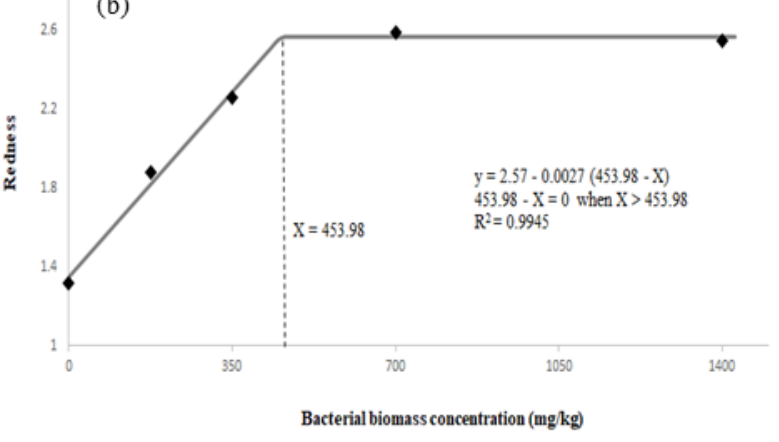


Figure 1. Fitted broken line plots of protein (a) and redness (b) in the tilapia fillets as a function of the biomass concentration in the experimental diets

Rancidity represents a problem to fish shelf life due to the sensory alterations it induces to flesh. Moreover, the reaction may even pose a risk to human health due to the formation of aldehydes, ketones, esters, hydrocarbons and others in the food [15]. In this trial, the bacterial biomass played a role in delaying the fillets rancidity, since slaughter and until 80 days of freezing storage (Table 3). This finding confirms the antioxidant effect previously assigned to the oxycarotenoids present in $R$. gelatinosus biomass [14].

Table 3. Means $( \pm$ SD) of the Thiobarbituric Acid Reactive Substances (TBARS) in the fillets of tilapia fed different concentrations of Rubrivivax gelatinosus biomass

\begin{tabular}{cccccc}
\hline \multirow{2}{*}{ Treatment } & \multicolumn{5}{c}{ TBARS (mg malonaldehyde $/ \mathrm{kg}$ ) } \\
\cline { 2 - 6 } & Day 0 & Day 20 & Day 40 & Day 60 & Day 80 \\
\hline Control & $0.071 \pm 0.025^{\mathrm{a}}$ & $0.343 \pm 0.048^{\mathrm{a}}$ & $0.647 \pm 0.090^{\mathrm{a}}$ & $0.800 \pm 0.046^{\mathrm{a}}$ & $0.807 \pm 0.028^{\mathrm{a}}$ \\
T1 & $0.040 \pm 0.002^{\mathrm{ab}}$ & $0.192 \pm 0.062^{\mathrm{b}}$ & $0.484 \pm 0.076^{\mathrm{b}}$ & $0.596 \pm 0.055^{\mathrm{b}}$ & $0.604 \pm 0.034^{\mathrm{b}}$ \\
$\mathrm{T} 2$ & $0.046 \pm 0.022^{\mathrm{ab}}$ & $0.155 \pm 0.028^{\mathrm{b}}$ & $0.378 \pm 0.048^{\mathrm{bc}}$ & $0.453 \pm 0.087^{\mathrm{c}}$ & $0.468 \pm 0.044^{\mathrm{c}}$ \\
T3 & $0.033 \pm 0.013^{\mathrm{b}}$ & $0.143 \pm 0.036^{\mathrm{b}}$ & $0.358 \pm 0.045^{\mathrm{bc}}$ & $0.447 \pm 0.032^{\mathrm{c}}$ & $0.453 \pm 0.036^{\mathrm{c}}$ \\
T4 & $0.033 \pm 0.009^{\mathrm{b}}$ & $0.124 \pm 0.034^{\mathrm{b}}$ & $0.317 \pm 0.069^{\mathrm{c}}$ & $0.444 \pm 0.061^{\mathrm{c}}$ & $0.459 \pm 0.039^{\mathrm{c}}$ \\
\hline P value & 0.0318 & $<0.0001$ & $<0.0001$ & $<0.0001$ & $<0.0001$ \\
\hline T1 - 175 mg/kg biomass; T2 $-350 \mathrm{mg} / \mathrm{kg}$ biomass; T3 - 700 mg/kg biomass; T4 $-1.400 \mathrm{mg} / \mathrm{kg}$ \\
biomass. Means followed by different superscripts differ significantly at Tukey's test $(\mathrm{p}<0.05$ ).
\end{tabular}

\section{Conclusion}

This study confirmed $R$. gelatinosus as an important agent in biotechnology, since its metabolism provided the remediation of the fish industry effluent and generated a product appropriate for use in animal feeding. The use of $R$. gelatinosus biomass in tilapias rations enhanced pigmentation, carotenoids and proteins in the muscles and delayed the rancidity of the flesh, so improving the quality of the fillets.

\section{Acknowledgements}

Authors thank Fundação de Amparo à Pesquisa do Estado de São Paulo for financial support and scholarships.

\section{References}

1. T. Bull, G. Holt and M. D. Lilly, Biotechnology: International Trends and Perspectives. Paris: Organisation for Economic Co-Operation and Development, 1982.

2. M. T. Madigan, J. M. Martinko and T. D. Brock, Brock Biology of microorganisms. Upper Saddle River, NJ: Pearson Prentice Hall, 2006.

3. E. H. G. Ponsano, M. F. Pinto, M. Garcia Neto and P. M. Lacava, "Evaluation of Rhodocyclus gelatinosus biomass for broiler pigmentation," J Applied Poult Res., vol. 11, pp. 77-82, 2002.

4. L. K. F Lima, E. H. G. Ponsano and M. F. Pinto, "Cultivation of Rubrivivax gelatinosus in fish industry effluent for depollution and biomass production," World J Microbiol Biotechnol, vol. 27, pp. 2553-2558, 2011.

5. E. H. G. Ponsano, L. K. F. Lima and A. P. C. Torres, "From a pollutant byproduct to a feed ingredient," in Biomass: detection, production and usage, D. Matovic, Ed. Rijeka: Intech, 2011, pp. 461-472.

6. W. Horwitz and G. W. Latimer Jr, Official Methods of Analysis of AOAC International. Gaithersburg: AOAC International, 2006.

7. E. F. E. Santo, L. K. F. Lima, A. P. C. Torres and E. H. G. Ponsano, "Comparison between freeze and spray drying to obtain powder Rubrivivax gelatinosus biomass," Ciênc Tecnol Aliment., vol. 
33, pp. 47-51, 2013.

8. R. C. Pereira, H. A. Pires, E. H. G. Ponsano, F. E. Mingato, D. B. Rozza and S. H. V. Perri, "Acute toxicological testing of biomass of Rubrivivax gelatinosus," Applied Research in Toxicology, vol. 2, pp. 136-136, 2017.

9. J. Folch, M. Lees and S. G. H. Sloanne, "A simple method for the isolation and purification of total lipid from animal tissues," J Biol Chem., vol. 226, pp.497-509, 1957.

10. W. Vyncke, "Direct determination of the thiobarbituric acid value in trichloracetic acid extracts of fish as a measure of oxidative rancidity," Eur J Lipid Sci Technol., vol. 72, no. 12, pp. 1084-1087, 1970.

11. Brasil, Resolução CONAMA $n^{o}$ 20. Brasília, Brazil: Conselho Nacional do Meio Ambiente (CONAMA), 1986.

12. Brasil, Resolução CONAMA $n^{\circ}$ 430. Brasília, Brazil: Conselho Nacional do Meio Ambiente (CONAMA), 2011.

13. R. T. M. Baker, A. M. Pfeiffer, F. J. Schöner and L. Smith-Lemmon, "Pigmenting efficacy of astaxanthin and canthaxanthin in fresh-water reared Atlantic salmon, Salmo salar," Anim Feed Sci Technol., vol. 99, pp. 97-106, 2002.

14. E. H. G. Ponsano, C. Z. Paulino and M. F. Pinto, "Phototrophic growth of Rubrivivax gelatinosus in poultry slaughterhouse wastewater," Bioresour Technol., vol. 99, pp. 3836-3842, 2008.

15. J. A. Ordoñez, Tecnologia de alimentos. Porto Alegre, Brazil: Artmed, 2005. 